\title{
An Innovative Therapeutic Approach for Breast Cancer: Engineered Mesenchymal Stem Cell-Derived Exosomes By Mir-145
}

\author{
HodaFazaeli, Ali Kowsari and Mohsen Sheykhhasan* \\ Department of Stem Cell, the Academic Center for Education, Culture and Research, Iran
}

Submission: August 11, 2018; Published: August 28, 2018

"Correspondence Address: Mohsen Sheykhhasan, Department of Stem Cell, the Academic Center for Education, Culture and Research, Qom Branch, Qom-Iran; Tel: +982532700152; Email: m.sheykhhasan@acecr.ac.ir

\section{Opinion}

Genetic changes cause progression and cancer metastasis, so the recognition of these changes will not only increase our understanding of the underlying mechanisms of cancer but also promote specific treatments in this area. Breast cancer has importance due to the progressive accumulation of multiple gene mutations that are associated with epigenetic disorders $[1,2]$.

Breast cancer is defined as an out of control change in cells growth of breast tissue, which is caused by abnormal growth in the milk glands (lobules) or in the ducts that connect the lobules to the nipple (duct) [3]. Breast cancer is the most common cancer in women and the second leading cause of death[4].Every year about one million women are diagnosed with this cancer worldwide. In the United States near to 255180 new cases are detected and the estimated mortality rate has been reported about 40,610 cases in 2017 [5].

Recent studies have shown that microRNAs (miRNAs) are a group of non-coding small RNAs regulating gene expression at the level of RNA by binding to the 3'UTR region of gene and prevention of its expression. These have vital roles in differentiation, proliferation, angiogenesis, and metabolism, so a disruption in these processes is expected to have consequences for cancer formation [6-9].

Several miRNAs have been introduced and studied with antitumor properties in breast cancer. MiR-145 is among the most important of them. MiR-145 is located on chromosome 5, which is a fragile region in the genome. This miRNA was first detected in mice and, after a short time, was also detected in human [10]. miR-145 had been identified as a tumour suppressor miRNA in various types of cancers such as kidney, prostate, bladder, lungs, and intestines. It can be delivered to target tissues and remains functional long enough to knock down the expression of the target protein [11]. However, the performance of miR-145 had not been investigated in breast cancer until 2016 when a study found that miR-145 was significantly reduced in breast cancer cell lines and tissues [12].

Further studies have shown that the ectopic expression of miR-145 reduces the proliferation and mobility of breast cancer cells, and its inhibition can amplify cell proliferation, migration, and invasion in vitro. These findings indicate that miR-145 acts as a tumour suppressor and that reduction of its expression could be involved in the development and metastasis of breast cancer[13]. Several genes in various cancers have been identified as target for miR-145 such as Matrix metalloproteinases (MMPs) [13], Insulin receptor substrate 1 (IRS1) [14], Homeobox A9 (HOXA9) [15], SRY-box 9 (SOX9) andAdducin 3[16], Disintegrin and Metalloproteinase domain-containing protein 17 (ADAM17) [17], Octamer-binding transcription factor 4 (OCT4) [18], Kruppel-like factor 4 (KLF4) [19], p70S6K1 [20], c-myc[21], mucin1 [22], and Rho-associated protein kinase 1 (ROCK1) [13].

In one study, it was shown that this function results from the targeting of the ROCK1 protein by miR-145. ROCK1 adjusts cell migration and connects to its substrate and controls rearrangement of the actin cytoskeleton. Increased expression of ROCK1 is associated with inhibition of this protein, which is associated with decreased mobility and cell invasion [13].

Also, Ding et al. showed that miR-145 can either directly or indirectly cause inhibition of breast cancer cells to proliferate or migrate through regulating TGF- $\beta 1$ expression [23].So that, miR145 can be recognized as a target for treatment and diagnosis of breast cancer. To do so and for creating any therapeutic effect by miR-145, targeted delivery of miRNA into tumour cells should be achieved.

According to evidences, mesenchymal Stem Cells (MSCs) are considered as appropriate tools to deliver cancer therapeutic agents. Although these cells are commonly present in bone 


\section{Cancer Therapy \& Oncology International Journal}

marrow, they can be isolated from various sources such as adipose tissue, liver, spleen, thymus, umbilical cord blood, placenta, Wharton's jelly, brain, lung, dental pulp, salivary glands, peripheral blood and some other tissues [24-26]. They are capable secretory cells which release a large number of extracellular vesicles (EVs) in the size range of 40-120 nm, called exosomes [27]. Exosomes are small vesicles with a phospholipid bilayer membrane and endocytic origin. In recent years a special attention has been paid to their relation with biologic and pathophysiologic processes. There is a growing body of evidences indicating that interaction between stem cells and human tumour cells in exchanging biological information is done via exosomes. These EVs are naturally enriched with miRNA and can transfer their content to recipient cells. They are able to exert phenotypic effect by playing role in processes like tumour genesis, angiogenesis, and tumour metastasis [28].

Previously, MSCs-derived exosomes were engineered with anti-mir-9 through transient transfection of parent cell [29]. Furthermore, in an in vivo model of glioma, some promising therapeutic effects were observed after direct injection of MSCs-derived exosomes, supplemented with mir-146, into the tumour[30].

Studies have confirmed the potential of applying exosomes as efficient vehicles for the delivery of miRNA to targeted cells and verified the inhibitory ability of miR-145 against various cancer types, especially breast cancer.Consequently, it could be strongly recommended that delivery of miR-145 via MSCsderived exosomes may consider as an innovative approach against breast cancer.

\section{References}

1. Olopade OI, Grushko TA, Nanda R, Huo D (2008) Advances in breast cancer: pathways to personalized medicine. Clin Cancer Res 14(24): 7988-7999.

2. Tan IB, Tan P, Tean TB. Personalized Medicine in Cancer.

3. Allred DC (2010) Ductal carcinoma in situ: terminology, classification, and natural history. J Natl Cancer Inst Monogr (41): 134-138.

4. Burkman RT (2012) Berek \& Novak's gynecology. JAMA 308(5): 516-7.

5. Siegel RL, Miller KD, Jemal A (2016) Cancer statistics, CA Cancer J Clin 66(1):7-30.

6. Deng X, Wu B, Xiao K, Kang J, Xie J, et al. (2015) MiR-146b-5p promotes metastasis and induces epithelial-mesenchymal transition in thyroid cancer by targeting ZNRF3. Cell Physiol and Biochem 35(1): 71-82.

7. Li D, Jian W, Wei C, Song H, Gu Y, et al. (2014) Down-regulation of miR-181b promotes apoptosis by targeting CYLD in thyroid papillary cancer. International journal of clinical and experimental pathology 7(11): 7672-7680

8. Xu Y, Zhao F, Wang Z, Song Y, Luo Y, et al (2010) MicroRNA-335 acts as a metastasis suppressor in gastric cancer by targeting Bcl-w and specificity protein 1 . Oncogene 31(11): 1398-1407.

9. Zhang X, Li M, Zuo K, Li D, Ye M, et al. (2013) Upregulated miR-155 in papillary thyroid carcinoma promotes tumor growth by targeting APC and activating Wnt/ $\beta$-catenin signaling. J Clin Endocrinol Metab 98(8): E1305-E13
10. Le Beau MM, Lemons RS, Larson R, Arai N, Rowley J (1989) Interleukin-4 and interleukin-5 map to human chromosome 5 in a region encoding growth factors and receptors and are deleted in myeloid leukemias with a del (5q). Blood 73(3): 647-650.

11. Zheng M, Sun X, Li Y, Zuo W (2016) MicroRNA-145 inhibits growth and migration of breast cancer cells through targeting oncoprotein ROCK1. Tumor Biology 37(6): 8189-8196.

12. Kim SJ, Oh JS, Shin JY, Lee KD, Sung KW, et al (2011) Development of microRNA-145 for therapeutic application in breast cancer. J Control Release 155(3): 427-434.

13. Tang L, Wei D, Yan F (2016) MicroRNA-145 functions as a tumor suppressor by targeting matrix metalloproteinase 11 and Rab GTPase family 27a in triple-negative breast cancer. Cancer gene Ther 23(8): 258-265.

14. Shi B, Sepp-Lorenzino L, Prisco M, Linsley P, Baserga R (2007) Micro RNA 145 targets the insulin receptor substrate- 1 and inhibits the growth of colon cancer cells. J Biol Chem 282(45): 32582-32590.

15. Shen WF, Hu YL, Uttarwar L, Passegue E, Largman C (2008) MicroRNA-126 regulates HOXA9 by binding to the homeobox. Molecular and cellular biology 28(14): 4609-4019.

16. Rani SB, Rathod SS, Karthik S, Kaur N, Muzumdar D, et al. (2013) MiR145 functions as a tumour-suppressive RNA by targeting Sox 9 and adducin 3 in human glioma cells. Neuro Oncol 15(10): 1302-1316.

17. Yu CC, Tsai LL, Wang ML, Yu CH, Lo WL, et al. (2013) miR145 targets the SOX9/ADAM17 axis to inhibit tumor initiating cells and IL-6-mediated paracrine effects in head and neck cancer. Cancer Res 73(11): 34253440

18. Cioce M, Ganci F, Canu V, Sacconi A, Mori F, et al. (2014) Protumorigenic effects of miR-145 loss in malignant pleural mesothelioma. Oncogene 33(46): 5319-5319

19. Liu H, Lin H, Zhang L, Sun Q, Yuan G, et al (2013) miR-145 and miR-143 regulate odontoblast differentiation through targeting Klf4 and Osx genes in a feedback loop. J Biol Chem 288(13): 9261-9271.

20. Xu Q, Liu L-Z, Qian X, Chen Q Jiang Y, et al. (2011) MiR-145 directly targets p70S6K1 in cancer cells to inhibit tumor growth and angiogenesis. Nucleic acids Res 40(2): 761-774.

21. Shao Y, Qu Y, Dang S, Yao B, Ji M (2013) MiR-145 inhibits oral squamous cell carcinoma (OSCC) cell growth by targeting c-Myc and Cdk6. Cancer cell international 13(1):51.

22. Sachdeva M, Mo YY (2009) MicroRNA-145 suppresses cell invasion and metastasis by directly targeting mucin 1 . Cancer Res 70(1): 378-387.

23. Ding Y, Zhang C, Zhang J, Zhang N, Li T, et al. (2017) miR-145 inhibits proliferation and migration of breast cancer cells by directly or indirectly regulating TGF- $\beta 1$ expression. Int J Oncol 50(5): 1701-1710.

24. Gebler A, Zabel O, Seliger B (2012) The immunomodulatory capacity of mesenchymal stem cells. Trends Mol Med 18(2): 128-134.

25. Lotfinegad P (2014) Immunomodulatory nature and site specific affinity of mesenchymal stem cells: a hope in cell therapy. Advanced pharmaceutical bulletin 4(1): 5 .

26. Wang M, Yang Y, Yang D, Luo F, Liang W, et al. (2009) The immunomodulatory activity of human umbilical cord blood-derived mesenchymal stem cells in vitro. Immunology 126(2): 220-232.

27. Yeo RWY, Lai RC, Zhang B, Tan SS, Yin Y, Teh BJ etal. (2003) Mesenchymal stem cell: an efficient mass producer of exosomes for drug delivery. Advanced drug delivery reviews 65(3): 336-641.

28. Valadi H, Ekström K, Bossios A, Sjöstrand M, Lee JJ, et al. (2007) Exosome-mediated transfer of mRNAs and microRNAs is a novel mechanism of genetic exchange between cells. Nat Cell Biol 9(6): 654 . 
29. Munoz JL, Bliss SA, Greco SJ, Ramkissoon SH, Ligon KL, et al. (2003) Delivery of functional anti-miR- 9 by mesenchymal stem cell-derived exosomes to glioblastoma multiforme cells conferred chemosensitivity. Mol Ther Nucleic Acids 2: e126
30. Katakowski M, Buller B, Zheng X, Lu Y, Rogers T, et al. (2013) Exosomes from marrow stromal cells expressing miR-146b inhibit glioma growth. Cancer Lett 335(1): 201-204.

\section{Your next submission with Juniper Publishers will reach you the below assets}

- Quality Editorial service

- Swift Peer Review

- Reprints availability

- E-prints Service

- Manuscript Podcast for convenient understanding

- Global attainment for your research

- Manuscript accessibility in different formats ( Pdf, E-pub, Full Text, Audio)

- Unceasing customer service

Track the below URL for one-step submission https://juniperpublishers.com/online-submission.php 